\title{
The Movement against Science Park Expansion and Electronics Hazards in Taiwan
}

A review from an environmental justice perspective

\section{Hua-mei Chiu}

\section{(2) OpenEdition}

\section{Journals}

Electronic version

URL: http://journals.openedition.org/chinaperspectives/6521

DOI: 10.4000/chinaperspectives.6521

ISSN: 1996-4617

\section{Publisher}

Centre d'étude français sur la Chine contemporaine

Printed version

Date of publication: 1 September 2014

Number of pages: 15-22

ISSN: 2070-3449

\section{Electronic reference}

Hua-mei Chiu, «The Movement against Science Park Expansion and Electronics Hazards in Taiwan », China Perspectives [Online], 2014/3 | 2014, Online since 01 January 2017, connection on 28 October 2019. URL : http://journals.openedition.org/chinaperspectives/6521 ; DOI : 10.4000/ chinaperspectives.6521 


\title{
The Movement against Science
}

\section{Park Expansion and Electronics}

\section{Hazards in Taiwan}

\author{
A review from an environmental justice perspective
}

HUA-MEI CHIU

\begin{abstract}
This article focuses on the growth and transformation of the movement against the expansion of science parks and electronics hazards in Taiwan. The author finds that the movement has brought about a strong overall trend against the industry's expansion and has gradually raised significant concern for environmental justice in the past decade. Concern for environmental and social justice has been interwoven to frame the movement's discourse and actions in the following three aspects: first, campaigning for procedural justice, democratic decision-making, and information transparency; second, campaigning for distributive justice of land, water, and environmental risk; and third, campaigning for the right of recognition.
\end{abstract}

KEYWORDS: environmental justice, environmental movement, high-tech electronics industry, electronic hazard, science park.

\section{Introduction}

$\mathrm{O}$ ver recent decades, as the electronics industry has expanded to many parts of the world, it has been found to have caused water overuse and contamination, air pollution, and ocean contamination. The industry's negative impact on the environment and natural resources became apparent in the Silicon Valley of California's Bay Area in the early 1980s, as exposed by groups such as the Silicon Valley Toxics Coalition. ${ }^{(1)}$ The chemical-intensive nature of electronics production also jeopardises the health of humans involved in the industry. Since the industry utilises massive amounts of chemicals, solvents, heavy metals, acids, toxic gases, etc., some of which are known or suspected to contain carcinogens and reproductive toxins, the impact of electronics hazards has generated the greatest concern among frontline workers and community residents. (2) For example, former electronics workers at IBM (USA), National Semiconductor (Scotland), RCA (Taiwan), and Samsung (South Korea) have brought the industry's health issues to public attention and have even filed lawsuits seeking compensation and justice from the 1990s to the present. (3)

In addition, the fact that the industry requires abundant land, water, and energy resources to fuel its rapid growth often raises concerns of social justice. Finite natural resources such as water and land have been re-allocated from farmers to electronics companies. In addition, planned obsolescence in electronic products creates enormous amounts of e-waste requiring disposal, and it is often the most impoverished labourers, even child labourers, in poor countries who are dismantling e-waste in toxic work environments. (4)

This has led activists from Silicon Valley to describe electronics production as a "toxic treadmill." (5) The authors of the seminal book Challenging the
Chips: Labour Rights and Environmental Justice in the Global Electronics Industry assembled scholars and activists from around the world to show that the global electronics industry is growing in lockstep with environmental injustice and labour rights violations.

As anti-electronics movements have developed and adopted the concept of environmental justice, the issue of equity in the distribution of environmental benefit and harm has become central to their concern. The environmental impact of the global electronics industry has been found to be unevenly distributed along the lines of social inequality, with frontline workers and neighbouring communities suffering the most from electronics hazards.

The author wishes to thank Paul Jobin, Ming-sho Ho, and two anonymous reviewers for valuable comments that helped improve on the initial draft.

1. Website of the Silicon Valley Toxics Coalition, http://svtc.org/about-us/history/ (accessed on 1 June 2014).

2. Leslie A. Byster et al.," The Electronics Production Life Cycle. From Toxics to Sustainability: Getting Off the Toxic Treadmill," in Ted Smith et al. (eds),Challenging the Chips: Labour Rights and Environmental Justice in the Global Electronics Industry, Philadelphia, Temple University Press, 2006, pp. 205-214.

3. In the 1980s, Joseph LaDou was the first scholar to study the occupational hazards of the semiconductor industry, warning that the workers were exposed to "systemic poisoning." See Joseph LaDou, "Occupational Heath in the Semiconductor Industry," in Ted Smith et al. (eds), Challenging the Chips: Labour Rights and Environmental Justice in the Global Electronics Industry, op. cit., Pp. 31-42. For the cases of IBM, National Semiconductor, and RCA, see the related articles in the same book, pp. 36-41, pp. 139-149, and pp. 181-190. The cases involving Taiwan's RCA workers are still on trial: see Paul Jobin and Yu-hwei Tseng, "Guinea Pigs Go to Court: Epidemiology and Class Actions in Taiwan," in Soraya Boudia, Nathalie Jas (eds), Powerless Science? Science and Politics in a Toxic World, Oxford, New-York, Berghahn Books, 2014, pp. 170-191. On the leukaemia cluster found among Samsung semiconductor workers in South Korea, see the website of the Supporters for the Health and Rights of People in the Semiconductor industry (SHARPS), http://stopsamsung.wordpress.com/ (accessed on 30 May 2014).

4. The most remarkable investigation of e-waste, Exporting Harm, was conducted and published by the Basel Action Network et al. in 2002, full text available on BAN's webpage, www.ban.org/Ewaste/technotrashfinalcomp.pdf (accessed on 30 May 2014).

5. Leslie A. Byster et al., "The Electronics Production Life Cycle," art. cit., p. 203. 
The toxic treadmill of the global electronics industry has provoked conflicts over the issues of environment, health, and labour rights in many parts of the world. In order to make the electronics industry accountable and sustainable, the International Campaign for Responsible Technology (ICRT), formed in 2002, has persistently advocated for the principles of environmental justice, precautionary principles, and extended producer responsibility. ${ }^{(6)}$ Movements have called not only for just distribution but also for the right to know and information transparency regarding the toxic chemicals used in the industry, the right to be recognised as stakeholders in corporations and in the political process, and the right to be compensated, etc. This echoes the threefold aspects of justice that David Schlosberg identified in the demands of the global environmental movement: "Equity in the distribution of environmental risk, recognition of the diversity of the participants and experiences in affected communities, and participation in the political processes which create and manage environmental policy." (7)

This article focuses on the growth and transformation of the movement against the expansion of science parks and electronics hazards in Taiwan over the past decade. It explores the political-economic context and the environmental changes from which the movement emerged. By exploring arguments within the movement since the mid-2000s, the article demonstrates that the movement has grown more robust with a central focus on environmental and social justice in three aspects related to distributive justice, political decision-making procedures, and the right of recognition.

The research principally adopted a qualitative research approach to review the history of environmental conflicts over electronics pollution and the expansion of Taiwan's science parks. This article draws on research done for my PhD thesis, completed in 2010, and a follow-up research project on recent changes in the regulation of hazardous chemicals in Taiwan's electronics industry. ${ }^{\left({ }^{8}\right)}$ Over the past decade, I have conducted more than 80 in-depth interviews with environmental activists, experts, government officials, managers, engineers, and workers in corporations. Related archival data, documents, and media reports were collected and analysed. The research is also informed by my participatory observations within institutional channels (e.g., Environmental Monitoring Group meetings, public hearings and Environmental Impact Assessment [EIA] reviews), and voluntary participation in meetings and collective actions by environmental organisations since 2001.

\section{Background: The evolution of the movement ${ }^{(9)}$}

In the late 1970s, the Taiwanese government selected the electronics industry as a strategic industry and established replicas of Silicon Valley in the form of science parks in which the electronics companies were clustered. The three main science parks, the Hsinchu Science Park (HSP), the Central Taiwan Science Park (CTSP), and the Southern Taiwan Science Park (STSP) were established in 1980, 1996, and 2003, respectively. To date, 13 industrial sites in these three science parks occupy 4,663 hectares of land with 873 companies employing 244,920 workers. ${ }^{(10)}$ The semiconductor and opto-electronics industries, which are the most capital- and chemicalintensive of the science park industries, have experienced significant growth. By 2012 , these two sectors accounted for $90 \%$ of the total turnover of the science parks and employed $82 \%$ of science park employees. ${ }^{(11)}$ Since semiconductor and opto-electronics manufacturers are also the biggest consumers of water, power, and land, as well as the main producers of toxic hazards, the growth of these two industries has spurred the emergence of the movement.

The movement emerged in the late 1990s when the HSP was found to be illegally discharging wastewater into rivers, rain drains, and irrigation channels, shattering its image as an environmental protection role model. In addition, several fires at semiconductor companies in 1996 and 1997 spewed hazardous chemicals into the air and exposed the environmental risk of the so-called clean and high-tech industry. As a result, local environmental activists lobbied the National Science Council (NSC) to form the first-ever Environmental Monitoring Group (EMG) at the end of 1999. However, activists' participation in the EMG proved ineffective in solving environmental and health problems such as residential complaints over odour and effluent pollution, the suspected causality between water contamination and cancer clusters, and disputes over the HSP sludge incinerator designed for handling toxic solvents generated by semiconductor companies. ${ }^{(12)}$

Another challenge for the movement was the difficulty of identifying the source of pollution. The companies and science parks persistently claimed that they were complying with environmental regulations, which were often out-dated in terms of regulating the chemicals used in electronics production. Meanwhile, the fact that firms have repeatedly evoked trade secrets in declining to provide comprehensive information has increased the difficulty of identifying the causality between pollution and the industry. ${ }^{(13)}$

During the 2000 presidential election, Democratic Progressive Party (DPP) candidate Chen Shui-bian highlighted the attractive prospect of a "Green Silicon Island" as part of his campaign, which ultimately ended the Kuomintang (KMT)'s 50 years of authoritarian rule. In order to fulfil political promises, however, the Chen government approved plans to develop the CTSP and expand the HSP and the STSP. ${ }^{(14)}$ The new plans for the science parks provoked more robust resistance against new sites for the HSP and the CTSP's Phase Three and Phase Four starting in 2006.

In addition, new cases of electronics pollution discovered since the mid2000s have been cited by activists as evidence for opposing science park expansion or have spurred the movement against electronics hazards. Notable pollution incidents included official confirmation of "green oysters" (contaminated by heavy metal) on the Hsinchu seashore, arsenic air pollution associated with opto-electronics companies, rice crops lost on farmland

6. ICRT, www.icrt.co/ (accessed on 1 December 2013)

7. David Schlosberg, "Reconceiving Environmental Justice: Global Movements and Political Theories," Environmental Politics, Vol. 13, No. 3, Autumn 2004, pp. 517-540.

8. Hua-mei Chiu, Ecological Modernization or Enduring Environmental Conflict? Environmental Change in the Development of Taiwan's High-tech Industry, PhD thesis at the Department of Sociology, University of Essex, UK, 2010. The research project, Xinxing huaxuepin guanzhi zhengce xia de Taiwan dianziye (Taiwan's electronic industry under the changing chemicals regulation), NSC 101-2410-H-110-001, was sponsored by Taiwan's National Science Council (NSC) from February 2012 to April 2013.

9. My previous work portrayed the trajectory of the movement and viewed the movement from the mid-2000s to 2010 as a one geared toward environmental and social justice. See Hua-mei Chiu, "The Dark Side of Silicon Island: High-Tech Pollution and the Environmental Movement in Taiwan," Capitalism, Nature and Socialism, Vol. 22, No. 1, 2011, pp. 40-57. Recent developments have allowed me to further clarify the dimensions of the environmental justice movement, as discussed in this article.

10. National Science Council, Xinshe (hankuojian) kexue yuanqu zhengce pinggu shuomingshu (Policy assessment of the new establishment and expansion of the science parks), Taipei, NSC, 2013, p. 1.

11. Ibid., pp. 3-12. The turnover of the semiconductor and opto-electronics industry is $54.6 \%$ and $35.7 \%$, respectively.

12. For more detailed discussion, see Hua-mei Chiu, Ecological Modernization or Enduring Environmental Conflict?, op. cit., pp. 187-209.

13. Ibid.

14. Council for Economic Planning and Development (CEPD), Lüse xidao jianshe lantu ji xiangguan zhengce fang'an (Blueprint and policy plan for a green silicon island), Taipei, CEPD, 2001. 
salinated by wastewater from the CTSP, pollution of the Shiaoli River by opto-electronics manufacturers AU Optronics Corporation (AUO) and Chuanghwa Picture Tubes Ltd. (CPT), and the most recent case of pollution of the Houjin River by the world's largest service provider for semiconductor testing and assembly, Advanced Semiconductor Engineering Inc. (ASE).

Overall, notable campaigns against the electronics industry in the past decade have focused on water contamination and environmental pollution, and have opposed land expropriation and water diversion, as well as protesting against increased health risks to residential communities. The campaigns have forged broader alliances between environmental organisations and grassroots groups of farmers, fishermen, and community residents. In order to resist developmental plans, the movement has increasingly focused on challenging the current decision-making process and asking for more participation in decision-making. The main battlefield usually starts with participation in the Environmental Impact Assessment (EIA) review and then shifts to the Regional Planning Review. Furthermore, in the movement against the CTSP Phase Three and Phase Four, cases were taken to the administrative court after the environmental camp failed to halt developmental plans through institutional participation. Since a governmental department the National Science Council (NSC), plays the role of developer, the government tends to protect the interests of developers and companies in these environmental disputes. As a result, confrontational strategies have frequently been adopted by activists. Environmentalists, farmers, and fishermen are often seen protesting outside the Environmental Protection Administration (EPA), the Construction and Planning Agency (CPA) of the Ministry of Interior, the Executive Yuan, and the Presidential Office Building, as well as holding protests at riversides, coastal areas, or along irrigation channels.

\section{The pursuit of environmental and social justice}

The movement over the past decade has shown a strong trend against the industry's expansion. The expansion of science parks and the electronics industry has come to be viewed as an unjust form of development, an injustice that is growing in lockstep with natural resource depletion and ecological degradation, deprivation of the livelihood of the powerless, unjust subsidies to high-tech capital, and lack of a democratic process in economic and environmental decision-making. Concern for environmental and social justice has been interwoven to frame the discourses and actions of the movement in three aspects: first, campaigning for procedural justice, democratic decision-making, and information transparency; second, campaigning for distributive justice of land, water, and environmental risk; and third, campaigning for the right of recognition.

\section{Campaign for democratic decision-making, information transparency, and procedural justice}

Along with concern over distributive justice, the movement has developed a strong criticism of an undemocratic decision-making process that excludes affected groups and lacks information transparency. The process of EIA review highlights the uneven power structure. By participating in the institutional decision-making process, local people, farmers, and environmentalists have confirmed their criticism of the unjust decision-making process.

In 2006, the movement made a breakthrough via its participation in the EIA review of CTSP Phase Three, which includes the Houli and Chihsin sites.
The DPP gave the movement a political opportunity through its reshuffling of the presidential cabinet in 2005. The new head of the EPA, Chang Kuolung, an environmental veteran and scholar, appointed several environmentalist scholars, lawyers, and organisers as EIA Committee members. During their term of office from August 2005 to July 2007, the environmentalist EIA committee members collaborated with several environmental organisations, including the Wild at Heart Legal Defense Association, the Taiwan Academy of Ecology, the Taiwan Environmental Action Network (TEAN), the Ecological Education Centre of the Kaohsiung Teachers' Association, the Taiwan Watch Institute, the Taiwan Environmental Protection Union, and Green Citizens' Action Alliance, and several lawyers from the Environmental Law Commission of the Taipei Bar Association (15) to review the new economic plans. The environmentalist EIA committee members found that the CTSP Phase Three EIA reports contained numerous flaws, lacked critical information and data, and tended to downplay social, environmental, and health consequences. For example, in the case of the Chihsin Site, the EIA statement applied data from the hydrology monitoring station upstream of the Dajia River to prove that there was enough water volume to dilute the high-tech wastewater, but avoided mentioning the fact that a dam diverted the river water mid-stream.

The environmental camp particularly focused on the problems of health risks to residents, water overuse and contamination, air pollution from volatile organic compounds (VOCs), and land expropriated from pear farmers. Critical information, especially on chemical substances and their effects, was lacking. The EIA review nevertheless approved the Houli and Chihsin sites under protest inside and outside of EIA meetings in February and June 2006. In the case of the Chihsin Site, two environmentalist EIA committee members resigned in protest, and four members walked out of the concluding meeting, accusing the government of "protecting the interests of big capitalists," "neglecting people's health," and "trampling on the EIA review." (16) As a result, farmers and environmental groups took the case to the administrative court on March 2007, arguing that the site was approved without proper assessment.

In the controversial review, environmentalist EIA committee members used their power to publicise the various impacts of the developmental plan, informed and mobilised local farmers, and attached all possible conditions to the EIA conclusion as the case was approved. The capacity of the movement showed notable enhancement. However, the environmentalist camp eventually failed to turn back the developmental plan or order the plan to go through a second, more comprehensive phase of EIA review, which would have involved wider public participation.

The uneven power structure of the EIA Committee is inherently biased towards the government's vow to remove "stumbling blocks" for capital. (17) The EIA committee consists of 14 experts nominated by the head of the

15. The general secretary of the Ecological Education Centre of the Kaohsiung Teachers' Association founded a new environmental organisation, Citizen of the Earth Taiwan (CET), in 2007.TEAN dissolved and joined CET in 2011. The active environmental lawyers later formed the Environmental Jurists Association in 2010.

16. EIA committee members collectively walked out and announced that "the EIA system has died"; see the statement by six EIA committee members, 30 June 2006, http://zh.wildatheart. org.tw/story/10/6122 (accessed on 30 July 2014). News reports in Ziyou shibao (Liberty Times), Zhongguo shibao (China Times), and Lianhebao (United Daily), 1 July 2006.

17. With the questions continuously raised by environmentalist EIA committee members during the EIA review and the prolonged protests of Huoli farmers outside the EPA, the EIA committee was not able to pass the plan for the Chihsin Site within one month as requested by Executive Yuan. The Executive Yuan ordered related departments to "resolve obstructions to the EIA review." The environmentalist EIA committee members were accused of being "stumbling blocks" to economic development. A statement was released by the environmentalist EIA committee members protesting governmental intervention in the EIA review: http://e-info.org.tw/node/5355 (accessed on 31 July 2014). 
EPA and seven representatives from different governmental departments, leaving room for government intervention.

In addition, the expert-oriented ElA review is based on the ideology of technological determinism ${ }^{(18)}$ and often leaves no room for substantial public participation. In the First Phase EIA review, the committee reviews the EIA statement submitted by the developer in the meeting room. Most cases since the EIA Act was enacted in 1994 have been approved via this paperwork review. Only controversial cases will be ordered to go through the second phase of EIA review, in which the case must undergo a more substantial and thorough review by the committee and the developer must publicly display the project plan and hold public meetings. The first phase ElA review provides no mechanism to ensure public participation.

As the EIA review has increasingly become an arena for environmental conflict, the EPA has established a rule stipulating that each residential and environmental organisation attending the EIA meeting is allowed to speak for only three minutes. This is particularly unfair to residents who live far away from the Taipei capital. For example, the Houli farmers, many of whom are elderly, normally have to leave Houli at 5:00 AM in order to attend the 9:00 AM meeting at the Taipei EPA office. An environmentalist commented: "There are normally hundreds of farmers coming together by coach, but their representative is only allowed to speak for three minutes at the meeting. It is just so unfair." (19) In first phase of EIA review, the developer only needs to hold a public meeting to explain the project after passing the review, which leaves no room for residents to understand let alone object to the plan - not to mention that most residents have not even been informed of or are unable to attend the meeting. The general method for the developers to inform residents is to place a notice of the meeting in a tiny corner of the local newspaper or put an announcement on a bulletin board in the neighbourhood or village office. Meetings have always been held during working hours on weekdays, making it difficult for residents to participate. One EIA committee member recalled a ridiculous case: "Only the head of the village showed up at the meeting. The rest of the participants were from the environmental consultancy company. It was held during working hours. Who could possibly attend the meeting?" (20)

For cases going through the second phase of EIA review, which requires developers to hold public meetings and public hearings, the opinions of the residents are hardly respected. The EIA review and the Regional Planning Review have been overwhelmingly dominated by officers and experts of the developmental state. Farmers and local people find that they have no say in the economic and environmental decisions that threaten their livelihood. Limited natural resources can be taken from them without prior consultation. For example, during the public hearing on CTSP Phase Three, the Houli farmers were surprised to learn that the Taiwan Joint Irrigation Association had already signed an agreement with the Science Park Administration and Taiwan Water Company on the diversion of irrigation water for industrial use, while the farmers had not been consulted at all. The farmers are often asked to give way to the high-tech electronics industry despite the fact that they have long paid for water rights and their right to access irrigation water is proclaimed in the General Principles of the Joint Irrigation Association.

In challenging the undemocratic decision-making process, the movement has called for information transparency regarding economic plans and information regarding hazards in the electronics industry. The earlier stage of the movement in the Hsinchu area had great difficulty ascertaining the actual environmental and health consequences of the HSP. In the past decade, the environmentalist camp has used participation in the EIA review to gain an understanding of the social and environmental costs of the development of science parks. During the review of CTSP Phase Three, environmentalist EIA committee members were able to use their influence to push the developer to provide more information about the development plans. This was described by environmentalists as a process in which "developers were forced to 'spit up' information little by little at each meeting." (21)

While the state and industry claimed that the companies fully complied with environmental regulations, the environmentalist camp gradually proved that there were flaws in the existing environmental regulation system for controlling electronics hazards. For instance, the environmentalist camp encountered great difficulty in obtaining the comprehensive Material Safety Data Sheet (MSDS) used by electronics companies. Environmentalist EIA committee members raised the issue at every EIA meeting, and developers were pushed to release new information during each meeting until they finally admitted that $5 \%$ of the raw materials had to remain confidential in order to protect trade secrets. ${ }^{(22)}$ In a public hearing held in the Legislative Yuan in September 2009, the officer of the Department of Environmental Sanitation \& Toxic Substance Management (DESTSM) of the EPA finally revealed the fact that the polluters of the Shiaoli River, the leading TFT-LCD manufacturers AUO and CPT, only declared 13 and three toxic substances, respectively, out of the 259 items regulated by the DESTSM.

Another example shows the flaws in the health impact assessment. After losing its lawsuit against the Houli farmers in January 2010, the EPA claimed there was no health risk associated with CTSP Phase Three as it selectively interpreted the conclusions of the health impact assessment, which was conducted according to the requirements of the EIA committee. A scholar participating in the assessment came out publicly saying that the assessment faced difficulty collecting comprehensive data about chemicals because the companies refused to provide them. The research group could only collect data from chimneys to analyse the substances that the air emissions contained. Moreover, the health impact assessment relating to high-tech wastewater, which concerned local farmers the most, was not even carried out due to budgetary restrictions. ${ }^{(23)}$ The fact that the corporations were reluctant or failed to provide relevant information through institutional channels contributed to the suspicions of local residents and environmentalists.

During the legal battle, society further witnessed the undemocratic side of the government. As mentioned, the environmental camp filed a lawsuit challenging the decision of the EIA review. In January 2008, the Taipei Administrative Court repealed the EIA review of the CTSP Third Phase Chihsin Site. Two years later, the Supreme Administrative Court dismissed the EPA's appeal and nullified the EIA review's conclusions regarding the Chihsin Site. The governmental sectors, both the EPA and the NSC, emphasised that there was no need to suspend operation of the park and alleged that the

18. Hsu Shih-jung and Hsu Shao-feng, "Yi minzhong guandian tan dao huanjing yingxiang pinggu zhidu (Research on the system of environmental impact assessment from the viewpoint of citizen participation), Taiwan tudi yanjiu (Journal of Taiwan Land Research), Vol. 2, pp. 101-130.

19. Interviewee NEA3, 28 February 2008, Taipei.

20. Interviewee ESE9, 12 March 2008, Taipei.

21. Interviewee NEA3, 5 September 2007, Taichung.

22. "Zhongbu kexue gongye yuanqu Houli yuanqu kaifa jihua, di'erci tingzheng huijilu" (Minutes of the second public hearing over the plan of the CTSP-Houli science park), 4 October 2007, pp. 183188. Available online at www.ctsp.gov.tw (Chinese only, accessed on 10 October 2007).

23. Wu Kwun-yu, "Zhongke sanqi jiankang fengxian pinggu de juxianxing" (The limits of health risk assessment of the CTSP phase three), Ziyou shibao (Liberty Times), 16 March 2010. 
interest of corporations is under government protection and that protecting corporate interests is consistent with the interests of the public. In order to reassert its legitimacy, the EPA held an extension meeting of the EIA review for the Chinsin Site, creating a precedent that allowed the developer to continue constructing and companies to continue operating while the EIA review was conducted. The second EIA, which the environmentalists ironically referred to as a "ghost EIA," (24) approved the project again at the end of August 2010 despite strong social dissent. As a result, environmental organisations and local farmers again filed lawsuits against the second EIA review. In March 2013, the environmentalist camp won the case again. But instead of stopping the SP operation, the EPA announced in January 2014 that the NSC would apply the case to the Second Phase of ElA review without interrupting the operation of the two companies already inside the park. The legal battle continues today.

\section{Distributive justice of environmental harm and benefit}

Along with campaigns against procedural injustice, the movement has developed resistance to the uneven distribution of environmental benefit and harm. In order to attract high-tech electronic investment, the Taiwanese government not only offers subsidies to the companies, but also plays the role of science park developer, providing essential infrastructure, extracting and redistributing natural resources, and tackling industrial waste. The debt of the government-run Science Park Operation Fund, mainly accumulated during the development of new science parks, has continued to increase, reaching more than NT\$128.4 billion (US\$4.28 billion) by the end of 2011. ${ }^{(25)}$ As new economic plans put increasing demand on land, water, and energy, and generate potential harm to ecology, the environment, and human health, the movement against the expansion of science parks has gradually focused on the distribution of environmental benefit and harm. The conflict over CTSP Phase Four illuminates the dimension of distributive injustice.

In 2008, the pro-developmental KMT won back the central government. A new economic development blueprint, "i-Taiwan 12 Projects," was announced by KMT President Ma Ying-jeou. It included the development of CTSP Phase Four in Changhua County, another important agricultural area in central Taiwan. However, the developmental plan has encountered resistance from environmentalists, farmers, and fishermen, with the problems of wastewater discharge and water contamination, land expropriation, and water use and diversion again becoming central issues in the dispute.

The first EIA review meeting on the new site was held on 7 April 2009. The issue of where to discharge the wastewater triggered protests from locals. With the cases of "green oysters," salinated farmland, and Shiaoli River pollution as evidence, electronics wastewater was not welcomed by local farmers and fishermen. In particular, the main user of the new site was AUO, the polluter of the Shiaoli River. Opto-electronics wastewater is hazardous and unacceptable for growing rice and raising oysters and cockles, according to the opposition. With assistance from environmental organisations, including the local group Changhua Environmental Protection Union, oyster farmers in Fushing District organised a self-help association and protested to the EPA, Changhua County government, and CTSP Administration during the EIA review.

The EPA was forced to hold a series of expert meetings to discuss the wastewater problem. ${ }^{(26)}$ The developer, the CTSP Administration, suggested the alternative solution of discharging wastewater into the Chuoshui River near the border of Changhua County and Yunlin County, in place of the original plan to discharge wastewater into the Old Chuoshui River in Changhua County. This change immediately spurred resistance from farmers and fishermen in Yunlin County. The Yunlin County government mobilised those farmers and fishermen to protest at the public meeting held by the CTSP Administration, and the Yunlin County Magistrate attended the EIA review meeting in person to raise strong objections to the new plan. Seeing the mobilisation in the adjoining County, the magistrate of Changhua County, who had been flaunting his success at convincing the central government to choose Changhua as the base for CTSP Phase Four, also objected to wastewater being discharged in Changhua County, where farmers and fishermen had voiced strong objections.

Despite local objections and suspicions, the Executive Yuan insisted that the EIA review must be passed as expected because top officials worried that delays in the construction schedule might upset the electronics companies. As a result, the EIA committee on 30 October 2009 passed the review conditionally with a bizarre solution to wastewater discharge: it left the CTSP Administration to decide where to discharge the wastewater because both options were allegedly safe and feasible. Furthermore, in order to diminish local objections, Premier Wu Dun-yi promised to build a pipe to discharge wastewater into the ocean three kilometres away from the coast. In response to the arbitrary conclusion of the EIA review, the environmentalist camp also took this case to the Administrative Court in 2010.

The alliance against CTSP Phase Four grew stronger when the case was reviewed in the Regional Planning Review Committee. Environmentalists argued that the development was inappropriate for its site and governmental investment. They noted that the occupancy rate of the industrial park near the proposed site of CTSP Phase Four was low, and that since the Science Park Operation Fund was heavy indebted, the government should not spend another NT\$48.96 billion, or US\$1.63 billion, to "swallow up" 631.09 hectares of farmland classified, according to the government's own regional plan, as fine agricultural land. In addition, the agricultural area is already under threat of water scarcity and land subsidence. Environmentalists pointed out that it was inappropriate to turn the area into an industrial park with huge water demand. (27)

Besides that, land grabs from the powerless to fulfil the needs of the science park has further eroded the legitimacy of the developmental plan. A small agriculture village with 31 households, Shansiliao, will be expropriated, and the farmers who have lived there for decades will be expelled from their land. The land expropriation was announced suddenly, and compensation to the farmers is minimal. One environmentalist criticised the injustice of land grabs: "It is a process of implementing injustice. In the name of public interest, the government takes away all that these old farmers own and

24. Chu Shu-Chuan, "Renmin nuhou: zhe shi yige gui huanping," (People roar: This is a ghost EIA), http://e-info.org.tw/node/58273 (accessed on 13 August 2010).

25. Lai Ling-ling, "Sanda kexue yuanqu fuzhai yibainian huan bu wan" (The debt for which the three science parks would need one hundred years to pay back), Shangye zhoukan (Business Weekly), No. 1191, 20 September 2012

26. The EPA instituted the "expert meeting" in the first phase EIA review in order to resolve a severe controversy. All parties in the dispute, such as local government, developers, and residential or environmental organisations, are allowed to recommend one or two experts to attend the expert meeting, joined by EIA committee members. The EIA review of CTSP Phase Four went through five sub-committee meetings and six expert meetings regarding the wastewater discharge problem.

27. Liao Ben-chain, "Tunshi tudi de yeman youxi" (Barbaric game of swallowing land), Taiwan shengtai xuehui dianzibao (Electronic Journal of the Taiwan Academy of Ecology), No. 259, 11 November 2009, http://ecology.org.tw (accessed on 30 June 2014). 
puts it into the pockets of the capitalists. This is the biggest injustice ever." (28) This soon attracted the attention of the farmers' movement, student movement, and bloggers, and the Shansiliao Support Group was formed.

With more disputes over the expropriation of people's land and homes for science parks by authorities and developers, local residents and farmers in Shansiliao in Changhua County, in Dapu and Wanbao in Miaoli County, and in Erchongpu and Puyu in Hsinchu County have organised themselves into self-help groups under the assistance of a farmer's rights group called Taiwan Rural Front. (29) A movement calling for land justice has emerged to challenge the legitimacy of land expropriation for science parks and new planned urban areas surrounding the science parks.

The water diversion from farms to the high-tech electronics industry has also resulted in social conflict. Farmers in Hsichou Township, Changhua County, formed the Alliance Against Water-Jacking by the CTSP in August 2011. Local people engaged in petitions, protests, and sit-ins in order to halt construction of a new underground aqueduct that will divert water from the Cizaipijun irrigation channels to the CTSP Phase Four. According to the farmers, water is already scarce; the Irrigation Association has been supplying water through the irrigation channels only four out of every ten days since the construction of ChiChi Weir, which supplies water to the Sixth Naphtha Cracker Plant of Formosa Plastics Group. Since then, farmers have had to spend NT\$40,000 to 300,000 to drill wells and pay extra electricity bills. Diversion of the water from the irrigation system may have major impact on 30,000 farming families and 180,000 hectares of farmland that rely on the Cizaipijun irrigation system. The anti-water-jacking alliance further argued that the Chuoshui River made Changhua and Yunlin County "the barn of Taiwan," providing $80 \%$ of Taiwan's eggs and cockles and $40 \%$ of its rice, vegetables, and pork. Without water, the farmland will die off and food security will be undermined. ${ }^{(30)}$

The development of CTSP Phase Four has triggered disputes over the issues of environment and land expropriation. In response to the government's strategies to pass the EIA review and Regional Planning review, ${ }^{(31)}$ 85 affected farmers worked with volunteering attorneys from the Environmental Jurists Association to file lawsuits against the government. On 11 October 2012, the Taipei High Administrative Court nullified the development permission in this case. The CTSP Administration filed a second appeal against this adjudication with the Supreme Administrative Court. Despite the fact that the main tenant, the AUO, announced the withdrawal of its investment from CTSP Phase Four on March 2012 due to the economic recession, the government refused to withdraw the developmental plan, deciding instead to turn the controversial site into an industrial park for precision machinery and related industry. These changes were approved by the EIA committee on 4 February 2013. Protests continued during the review, and the disputes continue to date.

Overall, the movement demonstrates a clear position of pursuing substantive justice against uneven distribution of environmental benefit and risk. The movement blames the developmental state and electronics companies for diverting water from agriculture to the electronics industry, grabbing farmers' land for the science park, and discharging wastewater that may contaminate the river that supplies irrigation, the groundwater for fish farms, and the wetlands for oyster farms. It is concerned about the possibility that air pollution and water contamination may harm the health of community residents and eventually have negative effects on the health of consumers through food consumption.
Also, a counter-discourse, including alternatives to the current unjust form of developmentalism, has been developed within the movement. The interests of high-tech electronic capital have long been viewed as the interests of the nation, but the movement is putting pressure on the developmental state to revise the national developmental path through a more democratic decision-making process and to exercise an appropriate role in environmental protection.

Environmentalists advocate an alternative form of development in which sustainable agriculture and living environment should be made the priority. In conflicts over the expansion of the CTSP, the potentially deleterious effects on agriculture and fisheries have particularly raised people's concern regarding issues of food security and safety. The criticisms of environmentalists claim, for instance, that "the alliance between the state and hightech capital has turned into a big monster eating land, water, and finite natural resources. It leaves no room for the next generation to survive," (32) and, "the hazardous consequences will ultimately catch us through the food supply chain as the toxic industrial wastewater discharged daily into the irrigation water for growing rice, vegetables, and fruits flows into the river and then to the ocean, where it pollutes coastal fishery products." (33) Bloggers and Internet users have echoed this argument by circulating statements such as, "in the future we cannot just eat IC wafers or panels." The movement's demands to protect agriculture are consistent with the rise of the movement campaigning for sustainable agriculture and food sovereignty.

\section{Campaign for the right of recognition}

Taiwanese society has witnessed the growth of social activist groups that have fought for the rights of affected people in disputes over the Science Park and electronics hazards since 2005. This development can be understood as the third dimension of environmental justice in the movement, campaigning for the recognition of the diversity of stakeholders and the experience of affected communities. As previously mentioned, the movement in recent years involved the most active environmental organisations across the country. These organisations consist of at least one full-time officer and volunteer professionals including scholars with social science, environmental science, or public health backgrounds, as well as volunteer lawyers. The movement has also attracted university students forming various types of support groups such as the Shiaoli River Youth Taskforce and the Anti-CTSP Youth either in local communities or on campus.

Most importantly, local farmers and fishermen have organised themselves into active associations and network with environmental organisations to reject the developmental plans threatening their livelihood. Some of them have also become activists to inform, support, and share information with farmers and fishermen affected by the science parks. In various campaigns,

28. Speech by Liao Ben-chain, a member of the Taiwan Academy of Ecology (Taiwan shengtai xuehui), during an interview on a Greenpeace Radio Station programme, 26 January 2010.

29. Taiwan Rural Front was founded in December 2008 by grassroots activists, farmers, and scholars concerned with farmers' rights, food sovereignty and security, and sustainable agriculture.

30. Website of Shouhu Cizaipijun (Guard the irrigation system of Cizaipijun- Hoklo for Cizipizhen), http://hsichou.blogspot.tw/ (accessed on 30 November 2013).

31. The Regional Planning review was passed on 12 November 2009.

32. Speech made by the environmentalist of Taiwan Academy of Ecology Liao Ben-chain during an interview for a programme of Greenpeace Radio Station, 26 January 2010.

33. Hua-mei Chiu, "Jike de kexue yuanqu, binsi de Taiwan nongye: cong zhongke Houli jidi di er ci tingzheng huitanqi" (Wipe out agriculture in order to establish the science parks: An observation on the second hearing of the CTSP-Houli site), Diqiu gongmin (Citizen of the Earth Taiwan), Vol. 2, Kaohsiung, CET, 2008. 
fishermen brought oyster shells and farmers brought fruit, flowers, vegetables, and sheaves of rice to highlight the threats of the electronics industry to fisheries and agriculture. Their actions have attracted public attention and have undermined the legitimacy of unjust form of development.

Furthermore, farmers with lay knowledge of meteorology, hydrology, farming, and land use have played a pivotal role in challenging official and elite knowledge in the decision-making process of EIA reviews. In the case of CTSP Phase Three, farmers collaborated with environmental organisations to challenge the technocratic and undemocratic outlook of the EIA review. For example, the Newchoukeng River was assigned as a stream to receive wastewater for the first four years before the wastewater channel for CTSP Phase Three was built. According to the ElA statement submitted by the developer, there was no farmland using the stream's water for irrigation, and the volume of water flowing in the stream was great enough to dilute the electronic wastewater. However, farmers easily pointed out that 200 hectares of farmland along the Newchoukeng River use its water for irrigation. It was also discovered that the flow of the stream shown in the EIA statement was much higher than the lay understanding of the farmers. EIA committee members subsequently located satellite photographs showing the existence of the farms as well as detailed data on water flow volume, which revealed that the EIA estimate was based on only three daily figures from the rainy season. ${ }^{(34)}$ As an EIA committee member indicated: "The knowledge of the farmers is comprehensive and valuable [...] their lay knowledge of the local aquatic environment and geography is far better than that of the technocrats." (35)

Seeking just recognition of stakeholders and the experience of affected communities has been significant in the movement against the CTSP. In the case of CTSP Phase Three, farmers, environmental groups, and lawyers have struggled for justice through the legal system for eight years. To date, the average age of the six farmers filing the lawsuit against the EPA is over 60 years old. Although the outcomes of the legal battle have repeatedly favoured the farmers (the dispute is not yet settled), the government has eroded the authority of the judicial system by continuing to protect companies from termination of operations. In retrospect, the farmers' persistent and uncompromising stand has challenged the legitimacy of the developmental state and the injustice inherent in a process that takes capitalist profits as the measure of development.

Furthermore, as in the case of its international counterparts, the recent movement in Taiwan has made an effort to be recognised as a stakeholder in electronics capital in order to push companies to take more responsibility for their misconduct and adopt environmental justice practices, precautionary principles, and extended producer responsibility. The Taiwanese government has long provided the physical walls of the science parks and centralised wastewater treatment as the best buffers keeping companies away from environmental conflict. The environmental movement has found it difficult to identify polluters or directly challenge corporations. In recent years, the environmental camp has had the opportunity to directly challenge companies outside the SPs, for example in the campaigns against pollution of the Shiaoli River in 2008 and of the Houjin River in 2014. In these campaigns, environmental organizations constantly highlighted the importance and necessity of companies recognising various social actors as stakeholders. In protests at the 2008 Corporate Social Responsibility forum held by Acer, the main client of the CPT and AUO, environmental groups raised the idea of stakeholders to challenge Acer: "meeting regulatory requirements on paper is by no means equivalent to meeting Corporate Social Re-

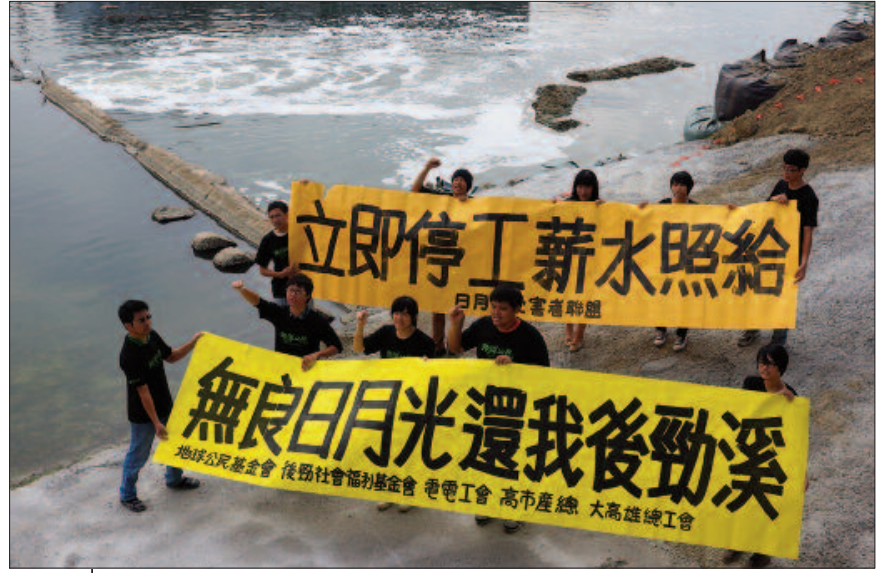

Photo 1 - After a press conference on 13 December 2013, activists from Citizen of the Earth Taiwan, local community groups, and trade unions protested on the bank of the Houjin River against wastewater pollution from ASE's plant (Advanced Semiconductor Engineering Inc.; in Chinese: 日月光半導體製 造股份有限公司). On the first placard: "Discourteous ASE, return the Houjin River to the people!" On the second placard: "Suspend operations without stopping salary payments [to workers]." @ Courtesy of Chih-nan Fu 傅志男

sponsibility standards. Acer should work with local stakeholders to press the Taiwan government for more holistic environmental regulations, operational procedures, and implementation standards." (36) Another example is the case of ASE in 2014. In order to make ASE, the world's leading provider of semiconductor packaging and testing services, accountable for its illegally discharging toxic wastewater polluting the Houjin River in Kaohsiung, Citizen of the Earth Taiwan (CET) has closely worked with the local community, farmers, and fishermen as well as trade unions, and called for these actors to be seen as stakeholders of a socially responsible corporation. (37) (See Photo 1)

Furthermore, CET also sought support from international counterparts to put pressure on ASE. On 12 February 2014, CET held an international press conference to release an international joint statement on ASE's corporate misconduct signed by 50 organisations and activists around the world. By leveraging the international campaign and putting pressure on the polluter through the global supply chain, it is becoming increasingly common for local environmental groups and the powerless to demand a say and recognition as stakeholders by powerful corporations. ${ }^{(38)}$

\section{Conclusion}

In this article, I argue that the movement challenging the expansion of science parks and the electronics industry in Taiwan has blossomed significantly not only in terms of size but also in concern over environmental and social justice. Since the mid-2000s, the movement can be seen to have

34. Hua-mei Chiu, "Chengjiu kexue yuanqu," art. cit.

35. Interviewee ESE9, 12 March 2008, Taipei.

36. Cited from the statement by the TEAN on "Taiwan Environmental Organisations Confront Acer and Urge the EU/America Consumers and Environmental NGOs Not to Be Deceived by Acer."

37. After the outbreak of ASE pollution, one of the appeals made by CET was to suspend the operations of ASE for investigation without stopping the payment of workers' salary. CET has invited local union activists and the newly formed Trade Union of Electrical, Electronics, and Information in Taiwan to join the protest on the bank of the Houjin River on 13 December 2013. See www.cettaiwan.org/node/1855 (accessed on 13 Dec 2013).

38. See the website of CET, www.cet-taiwan.org/node/1895 (accessed on 13 February 2014) 
transformed into a pursuit of just distribution of environmental benefit and risk, and of the right to participate in the decision-making process and the right to recognition.

The movement first of all focuses on the issue of social and environmental injustice resulting from high-tech expansion, such as natural resource depletion and ecological degradation, and the injustice to farmers and fishermen who were either deprived of their land or had their land and water resources polluted. One significant achievement of the movement is that environmental organisations have built networks with farmers, fishermen, and local people. This grassroots foundation has transformed the environmental movement into a movement with strong concern for social justice bringing together concern for environment and health, farmers' rights, sustainable agriculture, and responsible technology. Compared with its international counterparts, the movement challenging the electronics industry in Taiwan has built more solid links with farmers than with workers.

Second, disputes over the expansion of the electronics industry and science parks show that the current political power structure is biased in favour of the interests of electronics manufacturers; the economic and environmental decision-making process is insufficiently democratic, environmental regulations are out of date, and concerned groups have been denied the right to know and to be recognised. From EIA reviews to urban planning reviews to various public meetings or hearings, farmers and activists have protested against the lack of information transparency and the exclusion of public participation. In order to remedy the institutional flaws and political exclusion, environmental organisations advocate tighter environmental regulation under the precautionary principle. They also seek improved trans- parency, especially with respect to information on hazardous substances used in the electronics industry. Their advocates have turned to another joint effort to revise environmental regulations related to the electronics industry and science parks. The main actors, including Citizen of the Earth Taiwan, the Taiwan Watch Institute, the Environmental Jurist Association, and the Wild at Heart Legal Defense Association, have been working together to amend the Toxic Chemical Substances Control Act (TCSCA) since 2011, with the aim of meeting the international standard led by the European Union's REACH (Registration, Evaluation, and Authorization of Chemicals). It highlights the importance of sound management of chemicals, the adoption of the precautionary principle, "no-data-no-market" policy, reversing the burden of proof, right to know, and environmental and social justice principles. The new version of the TCSCA was finally approved by the Legislative Yuan in November 2013. However, to what extent the amendment can drive electronics companies and the state to make parallel and proportional improvements in environmental health and safety and social justice remains unclear. What is clear is that the environmental movement's increasing focus on environmental and social justice is and will remain a pivotal force in making high-tech electronics responsible and accountable, and in challenging the developmental state that often conceals the negative effects on the environment and public health.

\section{Hua-mei Chiu is Assistant Professor in Sociology at the National} Sun Yat-sen University.

Department of Sociology, National Sun Yat-sen University, 70

Lienhai Rd., Kaohsiung City 80424, Taiwan (fschiu@gmail.com). 